\title{
Physical Self-Concept of High School Students
}

\author{
Jajat Jajat ${ }^{1,2,{ }^{*}}$, Adang Suherman ${ }^{1}$, Yusuf Hidayat ${ }^{1}$, Mulyana Mulyana ${ }^{1}$ \\ ${ }^{1}$ Sports Education Program, ${ }^{2}$ Physical Education, Health and Recreation Program \\ ${ }^{1}$ Universitas Pendidikan Indonesia, ${ }^{2}$ Universitas Galuh Ciamis \\ ${ }^{1}$ Bandung, Indonesia, ${ }^{2}$ Ciamis, Indonesia \\ *jajat_kurdul@upi.edu
}

\begin{abstract}
The study aimed to investigate physical selfconcept differences based on gender and extracurricular involvement. Two hundred and three students, 112 were male and 91 females, 76 non-involvement extracurricular, 31 sports extracurricular and 96 other extracurricular involvement were completed: Physical Self-Description Questionnaire (PSDQ). Independent sample t-test was calculated to determine gender differences on physical self-concept, and One-Way ANOVA was calculated to determine based on extracurricular involvement. Significant differences were found on physical self-concept based on gender $(p<.000)$, and based on extracurricular involvement ( $p<.000)$. In addition, results showed that gender and extracurricular involvement influences toward physical selfconcepts. Students who are involved in extracurricular have better physical self-concept than those who do not. This finding implies that student involvement in extracurricular activities is very important.
\end{abstract}

Keywords-physical self-concept; PS; gender; extracurricular involvement

\section{InTRODUCTION}

Involvement in physical activity and regular exercise can have a positive impact both physiologically, psychologically and cognitive function [1]. Physical activity also has benefits to help psychological health [2]. Therefore research is also conducted on psychological perspectives that influence participation in physical activity [3].

Knowledge alone is not enough, because it turns out knowledge about the importance of physical activity is not positively correlated with physical activity behavior [4]. In general, everyone has the same barriers to physical activity [5].

One of the psychological effects of involvement in physical activity is on physical self-concept. Physical self-concept has a very important role in psychological constructs [6], and this terminology is a term used to describe individual awareness about the quality and limitations they have [7]. The lack of research examining the differences in physical self-concept in terms of extracurricular involvement is the basis of this research. Therefore, the main objective of this study is to examine differences in the effects of extracurricular involvement on physical self-concept.

\section{METHOD}

\section{A. Participants}

The subjects involved in this study amounted to 203 high school students, consisting of 112 men and 91 women aged 1617 years. Of 203 people, 76 people were not involved in extracurricular activities at school, 31 people were involved in sports extracurricular activities and 96 other people were involved in other extracurricular activities (non-sports).

\section{B. Measures}

The instrument used to measure physical self-concept is a Personal Self-Description Questionnaire (PSDQ) consisting of 11 scales; physical self-concept (Strength, Body Fat, Activity, Endurance/Fitness, Sport Competence, Coordination, Health, Appearance, Flexibility, General Physical Self-Concept, and Self-Esteem) and 70 question / statement items [8]. Subjects were asked to fill out a questionnaire according to the conditions they felt.

\section{Data Analysis}

SPSS Series 22 software were used to processing and data analysis. Description of data consists of average and standard deviations of physical self-concept based on gender and types of extracurricular involvement (not involved extracurricular, extracurricular sports and extracurricular non-sports). To find out the differences in physical self-concept based on gender, the independent sample t-test was used. To find out the physical self-concept based on extracurricular involvement, the One-way Anova test was used

\section{RESULTS AND DISCUSSION}

Descriptive statistics in Table 1 show the average and standard deviation of physical self-concept based on gender as a whole and based on extracurricular involvement. When viewed from the average, men overall have a higher physical self-concept score compared to women. Whereas based on extracurricular involvement, sports extracurricular groups have the highest average compared to sports extracurricular groups and those who are not involved in any extracurricular activities. 
TABLE I.

MEAN AND SD FOR PHYSICAL SELF-CONCEPT BY GENDER AND EXTRACURRICULAR INVOLVEMENT

\begin{tabular}{|l|c|c|}
\hline Physical Self-concept & M & SD \\
\hline Male & 242.87 & 38.58 \\
\hline Female & 211.85 & 38.80 \\
\hline NE & 204.04 & 35.70 \\
\hline SE & 220.13 & 36.92 \\
\hline NSE & 251.54 & 34.64 \\
\hline
\end{tabular}

Non-extracurricular $\mathrm{SE}=$ Sport extracurricula

NSE $=$ Non-Sport extracurricular

Based on the results of testing the independent sample t-test in Table 2 shows that there are differences in physical selfconcept between male and female adolescents ( $p$ <.000). Male teenagers have a higher physical self-concept score compared to females.

TABLE II. PHYSICAL SELF-CONCEPT DIFFERENCES BASED ON GENDER

\begin{tabular}{|c|l|l|}
\hline $\mathbf{t}$ & $\mathbf{p}$ & Mean Difference \\
\hline 5.682 & .000 & 31.02 \\
\hline
\end{tabular}

The masculinity and femininity factors are influence the risk factors of psychological conditions both internally and externally [9]. Gender is a moderator variable that is significant for the physical self-concept in general [10]. The cultural influence that is still strong in Indonesia related to gender issues in physical activity is also predicted to be one of the factors that differ in physical self-concept in adolescence. Heavy physical activity that requires strength and / or energy is seen as inappropriate for women in Indonesia.

In addition to these allegations, the presence of differences in involvement in physical activity between men and women has been widely expressed, where men are more involved in physical activity compared to women [11-14]. This is also predicted to affect differences in physical self-concept between male and female adolescents.

One-way Anova test results showed differences in physical self-concept between students involved in sports extracurricular activities, extracurricular non-sports and those who were not involved in extracurricular activities $(p<.000)$. Students involved in sports extracurricular activities are reported to have a higher physical self-concept compared to sports extracurricular activities and those who are not involved in extracurricular activities. While for students who are not involved in extracurricular activities have the lowest physical self-concept score among the three groups.
TABLE III. PHYSICAL SELF-CONCEPT DIFFERENCES BASED ON EXTRACURRICULAR INVOLVEMENT

ANOVA

\begin{tabular}{|l|c|l|c|c|c|}
\hline \multicolumn{7}{|c|}{ Physical Self-Concept } \\
\hline & $\begin{array}{c}\text { Sum of } \\
\text { Squares }\end{array}$ & df & $\begin{array}{c}\text { Mean } \\
\text { Square }\end{array}$ & F & Sig. \\
\hline $\begin{array}{l}\text { Between } \\
\text { Groups }\end{array}$ & 98569.486 & 2 & 49284.743 & 39.351 & .000 \\
\hline $\begin{array}{l}\text { Within } \\
\text { Groups }\end{array}$ & 250490.199 & 200 & 1252.451 & & \\
\hline Total & 349059.685 & 202 & & & \\
\hline
\end{tabular}

Table 4 shows which groups are different from physical self-concept. Extracurricular non-sport is different from nonextracurricular and extracurricular sports. Whereas extracurricular sports are no different from non-extracurricular.

TABLE IV. MULTIPLE COMPARISON

Dependent Variable: Physical Self-Concept Tukey HSD

\begin{tabular}{|l|l|l|l|}
\hline $\begin{array}{c}\text { (I) } \\
\text { Extracurricula } \\
\text { r Involvement }\end{array}$ & $\begin{array}{c}(\mathbf{( J )} \\
\text { Extracurricular } \\
\text { Involvement }\end{array}$ & $\begin{array}{c}\text { Mean } \\
\text { Difference (I-J) }\end{array}$ & Sig. \\
\hline \multirow{2}{*}{ Non-Sport } & Sport & $31.41263^{*}$ & .000 \\
\cline { 2 - 4 } & Non-Extra & $47.50219^{*}$ & .000 \\
\hline \multirow{2}{*}{ Sports } & Non-Sport & $-31.41263^{*}$ & .000 \\
\cline { 2 - 4 } & Non-Extra & 16.08956 & .086 \\
\hline Non-Extra & Non-Sport & $-47.50219^{*}$ & .000 \\
\cline { 2 - 4 } & Sport & -16.08956 & .086 \\
\hline \multicolumn{2}{|l|}{$*$ The mean difference is significant at the 0.05 level. } \\
\hline
\end{tabular}

Some studies state that involvement in physical activity has nothing to do with general physical self-concept and perceived competence [2,15-17]. This supports the results of research that extracurricular involvement does not guarantee that physical self-concept is also getting better.

Knowledge of the importance of physical activity is also not positively correlated with physical activity behaviour [4]. This is a possibility that involvement in extracurricular activities does not necessarily increase physical self-concept.

Apart from these results, this study still has limitations, including the disproportionate number of samples for each group, the possibility of understanding the different questioner items, and too many questions. Therefore, it is expected that further research can be carried out by taking into account the weaknesses and limitations that exist.

\section{CONCLUSION}

The results of this study indicate a significant difference between physical self-concept of male and female adolescents. In addition, involvement in extracurricular also shows a significant difference in physical self-concept. Hypothetically, the hope that students involved in sports extracurricular activities have better physical self-concept than others, but it turns out that the results of this study do not state this. 
However, this result requires a more in-depth study due to the disproportionate number of samples in each group. At least some studies suggest that gender influences involvement in physical activity, in this study it can also be.

\section{REFERENCES}

[1] W.J. Chodzko-Zajko, D.N. Proctor, M.A.F. Singh, C.T. Minson, C.R. Nigg, G.J. Salem, and J.S. Skinner, "Exercise and physical activity for older adults," Medicine \& science in sports \& exercise, vol. 41(7), pp. 1510-1530, 2009

[2] M. Hagger, B. Ashford, and N. Stambulova, "Russian and British children's physical self-perceptions and physical activity participation,' Pediatric Exercise Science, vol. 10(2), pp. 137-152, 1998

[3] S. Allender, G. Cowburn, and C. Foster, "Understanding participation in sport and physical activity among children and adults: a review of qualitative studies," Health education research, vol. 21(6), pp. 826-835, 2006.

[4] K. Sultoni, and M. Fitri, "Health-related fitness knowledge and its relation to college student physical activity," In IOP Conference Series: Materials Science and Engineering, vol. 180, no. 1, p.p 012212, 2017.

[5] S. Sultoni and A. Suherman, "Barriers to Physical Activity on University Student," In IOP Conference Series: Materials Science and Engineering, vol. 180, no. 1, pp. 012210, 2017.

[6] R.G. Craven and H.W. Marsh, "The centrality of the self-concept construct for psychological wellbeing and unlocking human potential: Implications for child and educational psychologists," Educational and Child Psychology, vol. 25(2), pp. 104-118, 2008.

[7] R.J. Shavelson, J.J. Hubner, and G.C. Stanton, "Self-concept: Validation of construct interpretations," Review of educational research, vol. 46(3), pp. 407-441, 1976.

[8] H.W. Marsh, G.E. Richards, S. Johnson, L. Roche, and P. Tremayne, "Physical Self-Description Questionnaire: Psychometric properties and a miiltitrait-meltimethod analysis of relations to existing instruments," Journal of Sport and Exercise psychology, vol. 16(3), pp. 270-305, 1994.

[9] J. Busfield, Gender and mental health. In The Palgrave Handbook of Gender and Healthcare. London: Palgrave Macmillan, 2010, pp. 172188.

[10] M.J. Babic, P.J. Morgan, R.C. Plotnikoff, C. Lonsdale, R.L. White, and D.R. Lubans, "Physical activity and physical self-concept in youth: systematic review and meta-analysis," Sports medicine, vol. 44(11), pp. 1589-1601, 2014

[11] S. Jandrić, "Differences between boys and girls in terms of physica activity," Facta Universitatis: Series Physical Education and Sport, vol. $8(1)$, pp. 1-7, 2010.

[12] A. Allafi, A.R. Al-Haifi, M.A. Al-Fayez, B.I. Al-Athari, F.A. Al-Ajmi, H.M. Al-Hazzaa, ... and F.Ahmed, "Physical activity, sedentary behaviours and dietary habits among Kuwaiti adolescents: gender differences," Public health nutrition, vol. 17(9), pp. 2045-2052, 2014

[13] J.A. Sarkin, T.L. McKenzie, and J.F. Sallis, "Gender differences in physical activity during fifth-grade physical education and recess periods," Journal of teaching in physical education, vol. 17(1), pp. 99106, 1997.

[14] H. Saffer, D. Dave, M. Grossman, M., and L. Ann Leung, "Racial, ethnic, and gender differences in physical activity," Journal of human capital, vol. 7(4), pp. 378-410, 2013.

[15] F.H. Asci, S.N. Kosar, and A.K. Isler, "The relationship of self-concep and perceived athletic competence to physical activity level and gender among Turkish early adolescents," Adolescence, vol. 36(143), pp. 499508, 2001.

[16] S. Biddle and N. Armstrong, "Children's physical activity: An exploratory study of psychological correlates," Social Science \& Medicine, vol. 34(3), pp. 325-331, 1992.

[17] D.L. Schmalz, G.D. Deane, L.L. Birch, and K.K. Davison, "A longitudinal assessment of the links between physical activity and selfesteem in early adolescent non-Hispanic females," Journal of Adolescent Health, vol. 41(6), pp. 559-565, 2007. 